\title{
SARS-Cov-2 fulminant myocarditis: an autopsy and histopathological case study
}

\author{
Guillaume Gauchotte ${ }^{1,2,3,4}\left(\mathbb{D} \cdot\right.$ Véronique Venard $^{5} \cdot$ Michaël Segondy $^{2} \cdot$ Cyril Cadoz $^{6} \cdot$ Aude Esposito-Fava $^{2}$. \\ Damien Barraud $^{6} \cdot$ Guillaume Louis $^{6}$
}

Received: 23 November 2020 / Accepted: 17 December 2020 / Published online: 3 January 2021

(C) The Author(s), under exclusive licence to Springer-Verlag GmbH, DE part of Springer Nature 2021

\begin{abstract}
The coronavirus disease 2019 (COVID-19), due to SARS-CoV-2, is primarily a respiratory disease, causing in most severe cases life-threatening acute respiratory distress syndrome (ARDS). Cardiovascular involvement can also occur, such as thrombosis or myocarditis, generally associated with pulmonary lesions. Little is known about SARS-CoV-2-induced myocarditis. We report the case of a 69-year-old man suffering from a refractory cardiogenic shock, without significant lung involvement. Prior to death, several nasopharyngeal swabs and distal bronchoalveolar lavage were sampled in order to perform RT-PCR analyses for SARSCoV-2-RNA, which all gave negative results. Autopsy showed coronary atherosclerosis, without acute complication. Microscopic examination of the heart revealed the existence of an intense multifocal inflammatory infiltration, in both ventricles and septum, composed in its majority of macrophages and CD8+ cytotoxic T lymphocytes (CD4/CD8 ratio: 0.11). Immunohistochemistry for anti-SARS nucleocapsid protein antibody was strongly positive in myocardial cells, but not in lung tissue. RT-PCR was realized on formalin-fixed paraffin-embedded lung and heart tissue blocks: only heart tissue was positive for SARS-CoV-2 RNA. In conclusion, this exhaustive post-mortem pathological case study of fulminant myocarditis demonstrates the presence of SARS-CoV-2 RNA in heart tissue, without significant lung involvement. Immunohistochemistry showed that the virus was specifically localized in cardiomyocytes and induced a strong cytotoxic $\mathrm{T}$ cells inflammatory response. This case report thus gives new insight in the pathogenesis of SARS-CoV-2-induced myocarditis and emphasizes on the importance and reliability of post-mortem analyses in order to better understand the physiopathology of this worldwide spreading new viral disease.
\end{abstract}

Keywords SARS-Cov-2 $\cdot$ COVID-19 $\cdot$ Myocarditis $\cdot$ Autopsy $\cdot$ Histopathology

Guillaume Gauchotte

g.gauchotte@chru-nancy.fr

1 Department of Biopathology, CHRU Nancy, CHRU/ICL - bâtiment BBB, Rue du Morvan, 54511 Vandoeuvre-lès-Nancy, France

2 Department of Legal Medicine, CHRU Nancy, Vandoeuvre-lès-Nancy, France

3 INSERM U1256, NGERE, Faculty of Medicine, Université de Lorraine, Vandoeuvre-lès-Nancy, France

4 Centre de Ressources Biologiques, BB-0033-00035, CHRU, Nancy, France

5 Department of Virology, CHRU Nancy, Vandoeuvre-lès-Nancy, France

6 Department of Intensive Care Medicine, CHR Metz-Thionville, Ars-Laquenexy, France

\section{Introduction}

The new SARS-Cov-2 pathogen, causing coronavirus disease 2019 (COVID-19), was identified for the first time in December 2019, in China. Cases of COVID-19 have now been reported all around the world, resulting in 2020 in more than one million of deaths, which are consecutive in most of cases to a life-threatening acute respiratory distress syndrome (ARDS). Cardiovascular involvement can also occur, such as thrombosis or myocarditis, generally associated with pulmonary involvement [1-5]. To date, little is known about SARSCov-2-induced myocarditis. Several cases of fulminant myocarditis have been reported [6-11], with only few cases of histopathological assessment.

In the present study, we report a case of isolated fulminant myocarditis, including exhaustive post-mortem histopathological, immunohistochemical, and viral analyses. 


\section{Case report}

A 69-year-old man with a history of diabetes, hypertension, and ischemic heart disease, but without chronic heart failure, presented to the emergency room with fever, asthenia, and abdominal pain that had been progressing for a week. Physical examination was unremarkable. Initial blood analysis demonstrated high inflammatory markers and lymphopenia (white blood cell count, 14 460/mm3; neutrophils, 13710/ mm3; lymphocytes, 540/mm3; C-reactive protein, $329 \mathrm{mg} / \mathrm{L}$ ). Arterial blood gas analysis showed compensated metabolic acidosis with hyperlactacidemia $(\mathrm{pH}, 7.51$; excess basis, 9 $\mathrm{mEq} / \mathrm{L}$; lactates, $3 \mathrm{mmol} / \mathrm{L}$ ) and normoxemia. Blood cultures were sterile. Reverse transcription polymerase chain reaction (RT-PCR) analysis for SARS-CoV-2 was negative on a nasal swab sample. A computed tomography (CT) scan showed no anomaly in the thoracic and abdominal areas. An electrocardiogram was performed and did not show signs of ischemia.

During the first hours of his hospitalization, the patient remained hypotensive, hypoxemic, and anuric. The echocardiogram showed a non-dilated left ventricle (LV) and severe and diffuse LV hypokinesia (LV ejection fraction: $30 \%$ ). He was admitted in the intensive care unit (ICU) with a diagnosis of acute myocarditis. New biological test revealed elevated levels of markers of myocyte necrosis (high-sensitivity troponin I level of $8066 \mathrm{pg} / \mathrm{mL}$ and creatine kinase-MB level of $2103 \mathrm{UI} / \mathrm{L}$ ), severe metabolic acidosis with hyperlactacidemia ( $\mathrm{pH}, 7.13$; lactates, $6 \mathrm{mmol} / \mathrm{L}$ ), and acute kidney injury KDIGO 3. He required vasopressor therapy (noradrenalin) and inotropic support (dobutamine). He developed increasing dyspnea requiring orotracheal intubation a few hours after admission. Urgent coronary arteriography was performed and showed non-significant lesions and two permeable stents. Search for common cardiotropic infectious agents, especially influenza infection, yielded negative results.

Three other RT-PCR SARS-CoV-2 analyzes were negative on sampling of deeper airway samples (tracheal secretions and bronchoalveolar lavage).

Two days after ICU admission, LV ejection dropped to $20 \%$, and estimated cardiac index was $1.5 \mathrm{~L} / \mathrm{min} / \mathrm{m}^{2}$. There was a circumferential pericardial effusion around the right cardiac chamber without signs of tamponade.

Severe myocardial dysfunction and severe hemodynamic compromise quickly led to implementation a veino-arterial extracorporeal membrane oxygenation (VA-ECMO). The patient deceased 6 days after admission, in a context of refractory shock and multi-organ failure.

A medical autopsy was performed 2 days after death. The lungs were congestive, without significant hepatization. The heart weighted $403 \mathrm{~g}$. Coronary arteries showed calcified atherosclerosis and contained two permeable stents, localized in the circumflex branch of the left coronary artery and in the right coronary artery. A mild hemorrhagic infiltration was observed around ascendant aorta. No other macroscopic anomaly was found.

Gross examination of formalin-fixed heart was then achieved in the Department of Pathology, with prior decalcification of coronary arterial segments, when necessary. It revealed an $80 \%$ stenosis of the right coronary artery, without any hemorrhagic or thrombotic complication, and confirmed the permeability of the stents. Myocardium sections showed a grayish centimetric scar within the posterior wall of left ventricle.

After fixation in $4 \%$ neutral buffered formalin for 1 week and sampling of the different organs, $4 \mu \mathrm{m}$ thickness tissue sections were performed and stained with hematoxylin, eosin, and saffron. Microscopic examination of the heart revealed the existence of a multifocal inflammatory infiltration, in both ventricles and septum, composed in its majority of macrophages and lymphocytes (Fig. 1), associated with a mild polymorphonuclear neutrophils infiltrate. The myocardium was edematous, containing dystrophic cardiomyocytes, without necrosis. An hypocellular confluent area of fibrosis was found in posterior wall of left ventricle. There was no significant inflammatory infiltrate in the wall of capillaries and vessels.

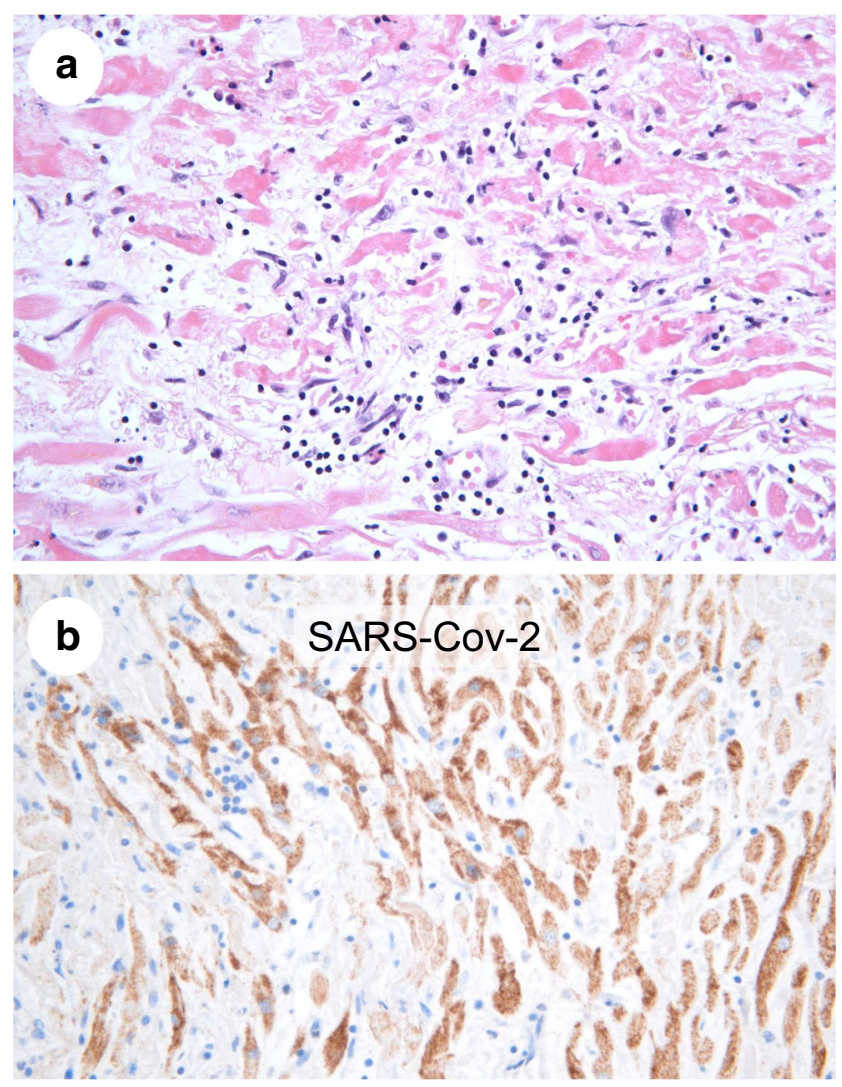

Fig. 1 (a) Abundant myocardium edema and interstitial inflammation, showing a predominance of mononucleated leucocytes, associated with cardiomyocytes dystrophies (hematoxylin, eosin, and saffron (HES), $\times$ 200). (b) Strong granular cytoplasmic staining of cardiomyocytes for SARS coronavirus nucleocapsid protein (immunohistochemistry, $\times 200$ ) 
In lung parenchyma, alveolar spaces were focally filled with a fibrine exudate, associated with a mild macrophagic alveolitis, without pneumocytes dystrophy. No fibrosis was seen. Liver parenchyma showed a moderate macrovacuolated steatosis and an abundant peri-portal fibrosis associated with porto-portal septa. Multifocal centro-lobular necrosis was also observed, without significant inflammation. Acute tubular necrosis was observed in the kidney, without inflammation. Pancreas showed a pluri-focal moderate lymphocytic and macrophagic inflammation and few phenomena of necrosis. Histopathological examination of the brain, spleen, colon, small intestine, stomach, adrenal glands, and thyroid revealed no specific anomaly.

After pretreatment of formalin fixed tissue sections for $40 \mathrm{~min}$ at $97{ }^{\circ} \mathrm{C}$ (Envision Flex TRS, Low pH; Dako Cytomation, Glostrup, Denmark), an immunohistochemical assay was performed with an anti-SARS-CoV nucleocapsid protein antibody (SARS-CoV nucleocapsid protein antibody, rabbit polyclonal, NB100-56576 Novus Biologicals, 1/50, 30 min of incubation; Flex+ Envision revelation system, Envision Flex+ rabbit Linker, prediluted, $10 \mathrm{~min}$; Dako Omnis) on lung, myocardium, pancreas, and kidney samples. It revealed a strong multifocal granular cytoplasmic staining of cardiomyocytes (Fig. 1), without significant staining of the lung, kidney, or pancreas. Additionally, in heart tissue, immunohistochemistry with the anti-CD163 antibody outlined the presence of numerous interstitial macrophages (Fig. 2), and anti-CD20,-CD3, -CD4, and -CD8 antibodies showed that the vast majority of lymphocytes were $\mathrm{CD} 3+, \mathrm{CD} 8+$, and TIA-1 cytotoxic $\mathrm{T}$ lymphocytes (CD4/CD8 ratio: 0.11) (Fig. 2, Table 1).

Finally, RNA was extracted from formalin-fixed paraffin-embedded heart and lung tissue blocks, in order to perform RT-PCR, which allowed to detect SARS-CoV-2 (COVID-19) genome in heart tissue, but not in lung parenchyma. Analyses for influenzae (A and B) and parvovirus B19 were negative.

\section{Discussion}

In this original post-mortem report, we analyzed a case of fulminant myocarditis, without significant lung involvement. None of the pre-mortem analyzes allowed to obtain an appropriate diagnosis. Notably, all SARS-CoV-2 RT-PCR were negative, including nasal swabs well as tracheal secretions and bronchoalveolar lavage. This could be explained by the isolated localization of the virus in the myocardium, in our case without significative replication of the virus in the upper respiratory airways and lung tissue at the time of hospitalization. The presence of SARS-CoV-2 in heart tissue was proven in only few studies, in most of cases in patients with positive nasopharyngeal swabs and/or lung involvement [9, 12-14]. To our knowledge, only two cases of isolated SARS-CoV-2 myocarditis were reported, with favorable outcome. In these two young patients, the nasopharyngeal swabs were negative, but the RT-PCR assays which were performed on endomyocardial biopsies were positive [13]. This supports the indication of endomyocardial biopsies with histological and virological analyzes, as proposed by the Wuhan international workshop on fulminant myocarditis [15]. In addition, the present report also suggests that anti-SARS-CoV-2 immunohistochemistry could be a useful and easy-to-use tool to detect viral proteins, prior to RT-PCR assay, notably for the forensic pathologist (Fig. 1).

The pathophysiology of SARS-CoV-2-induced myocarditis is still not fully elucidated. Tavazzi et al., using electron microscopy, reported viral particles detection in myocardial interstitial cells, but not in cardiomyocytes nor endothelial cells [16]. We demonstrate in the present case that SARSCoV-2 can directly infect cardiomyocytes, which is concordant with the expression of ACE2 in these cells [17]. Only one case of direct infection of cardiomyocytes was very recently reported: Albert et al., using electron microscopy, demonstrated the presence of viral particles in myocytes sarcoplasm [18]. Viral infection of cardiomyocytes could induce direct cell
Fig. 2 (a) Anti-CD163 antibody showing numerous interstitial macrophages. (b) Abundant T cell lymphocytes inflammation outlined by the anti-CD3 antibody. (c) Most of T cells are CD8positive lymphocytes (CD4/CD8 ratio: 0.11$)$. (d) Staining with antiTIA-1 antibody (left), showing abundant cytotoxic T lymphocytes, part of them being activated, granzyme B positive (right) (immunohistochemistry, original magnification $\times 200$ )

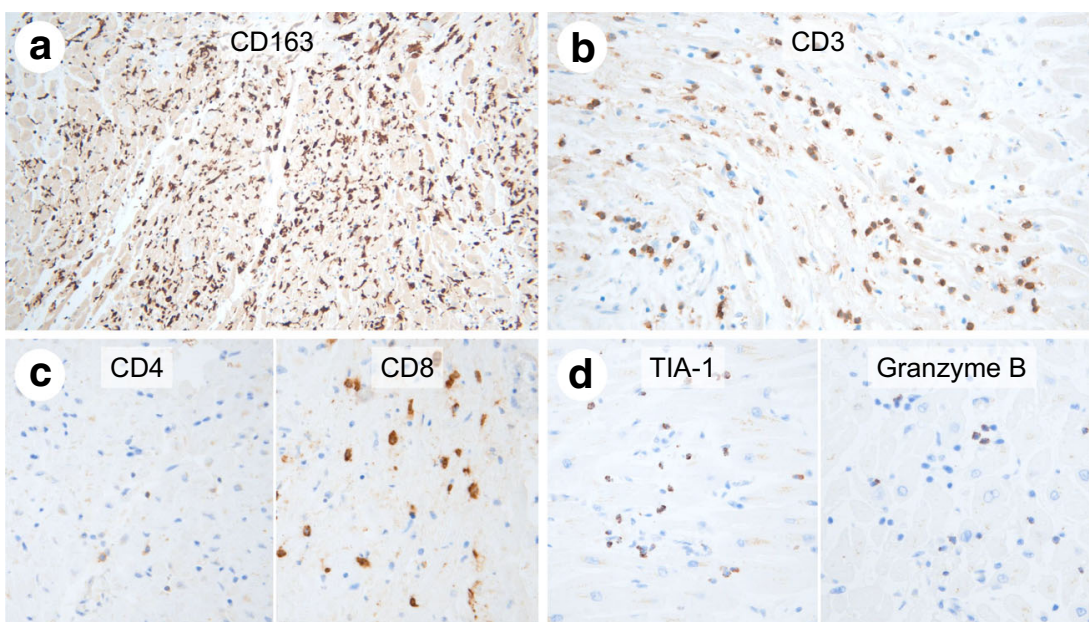


Table 1 Quantitative evaluation of myocardial inflammatory cells

\begin{tabular}{lllllllll}
\hline & CD163 & CD15 & CD20 & CD3 & CD4 & CD8 & $\begin{array}{l}\text { Tia- } \\
1\end{array}$ & Granzyme B \\
\hline Cells/10 HPF & 197 & 20 & 9 & 84 & 9 & 83 & 80 & 43 \\
\hline
\end{tabular}

$H P F$ high power fields

Immunohistochemistry, number of cells per 10 high power fields (HPF; $2.37 \mathrm{~mm}^{2}$ ) damages, but also indirect damages through a specific $\mathrm{T}$ cell cytotoxic immune response. Indeed, we found in our case a high proportion of CD8+ TIA $1+$ T lymphocytes. Approximately half of these cytotoxic cells were activated, characterized by an expression of granzyme B (Table 1, Fig. 2d). Similarly, Wenzel et al. reported abundant perforinpositive cytotoxic $\mathrm{T}$ cells, in the two cases of isolated myocarditis [13]. On the contrary, in a multicenter cardiovascular pathology study, Basso et al. reported a predominance of CD4-positive T helper cells. However, only 3 out of 21 patients had a lymphocytic myocarditis, whereas all patients had positive nasopharyngeal swab for SARS-CoV-2, and in most of cases ARDS. Specific detection of SARS-CoV-2 in heart tissue was not reported [2]. The present case report suggests that SARS-CoV-2-induced fulminant myocarditis could be induced by a direct infection of cardiomyocytes associated with an intense cytotoxic $\mathrm{T}$ cell immune response. This is concordant with the in vitro study reported by Bojkova et al. [17]. Further in vivo observations are needed in order to support this hypothesis.

In conclusion, this case study thus gives new insights in the pathogenesis of SARS-CoV-2-induced fulminant myocarditis and emphasizes on the importance and reliability of postmortem analyses. In this pandemic context of COVID-19, the forensic pathologist should keep in mind the eventuality of a SARS-CoV-2-induced myocarditis and thus sudden death, even in the absence of lung injury and negative nasopharyngeal swabs. Immunohistochemistry and FFPE tissue blocks-based SARS-CoV-2 RT-PCR can be useful to achieve this diagnosis.

\section{Compliance with ethical standards}

Conflict of interest The authors declare that they have no conflict of interest.

Ethical approval This study was lead in the respect of the French law relevant to medical autopsy and bio-medical research.

Informed consent The family consent was obtained for autopsy and case report.

\section{References}

1. Maiese A, Manetti AC, La Russa R et al (2020) Autopsy findings in COVID-19-related deaths: a literature review. Forensic Sci Med Pathol. https://doi.org/10.1007/s12024-020-00310-8
2. Basso C, Leone O, Rizzo S, de Gaspari M, van der Wal AC, Aubry MC, Bois MC, Lin PT, Maleszewski JJ, Stone JR (2020) Pathological features of COVID-19-associated myocardial injury: a multicentre cardiovascular pathology study. Eur Heart J 41:38273835. https://doi.org/10.1093/eurheartj/ehaa664

3. del Nonno F, Frustaci A, Verardo R, Chimenti C, Nicastri E, Antinori A, Petrosillo N, Lalle E, Agrati C, Ippolito G, on behalf of the INMI COVID study group (2020) Virus-negative myopericarditis in human coronavirus infection: report from an autopsy series. Circ Heart Fail 13. https://doi.org/10.1161/ CIRCHEARTFAILURE.120.007636

4. Edler C, Schröder AS, Aepfelbacher M, Fitzek A, Heinemann A, Heinrich F, Klein A, Langenwalder F, Lütgehetmann M, Meißner K, Püschel K, Schädler J, Steurer S, Mushumba H, Sperhake JP (2020) Dying with SARS-CoV-2 infection-an autopsy study of the first consecutive 80 cases in Hamburg, Germany. Int J Legal Med 134:1275-1284. https://doi.org/10.1007/s00414-020-02317-w

5. Dettmeyer R, Lasczkowski G, Weber A et al (2020) Histopathological findings following SARS-CoV-2 infection with and without treatment-Report of three autopsies. Rechtsmed Berl Ger:1-8. https://doi.org/10.1007/s00194-020-00408-x

6. Lara D, Young T, Del Toro K et al (2020) Acute fulminant myocarditis in a pediatric patient with COVID-19 infection. Pediatrics 146:e20201509. https://doi.org/10.1542/peds.2020-1509

7. Bernal-Torres W, Herrera-Escandón Á, Hurtado-Rivera M, PlataMosquera CA (2020) COVID-19 fulminant myocarditis: a case report. Eur Heart J Case Rep 4:1-6. https://doi.org/10.1093/ehjcr/ ytaa2 12

8. Zeng J-H, Liu Y-X, Yuan J, Wang FX, Wu WB, Li JX, Wang LF, Gao H, Wang Y, Dong CF, Li YJ, Xie XJ, Feng C, Liu L (2020) First case of COVID-19 complicated with fulminant myocarditis: a case report and insights. Infection 48:773-777. https://doi.org/10. 1007/s15010-020-01424-5

9. Kesici S, Aykan HH, Orhan D, Bayrakci B (2020) Fulminant COVID-19-related myocarditis in an infant. Eur Heart J 41:30213021. https://doi.org/10.1093/eurheartj/ehaa515

10. Naneishvili T, Khalil A, O'Leary R, Prasad N (2020) Fulminant myocarditis as an early presentation of SARS-CoV-2. BMJ Case Rep 13:e237553. https://doi.org/10.1136/bcr-2020-237553

11. Garot J, Amour J, Pezel T, Dermoch F, Messadaa K, Felten ML, Raymond V, Baubillier E, Sanguineti F, Garot P (2020) SARSCoV-2 fulminant myocarditis. JACC Case Rep 2:1342-1346. https://doi.org/10.1016/j.jaccas.2020.05.060

12. Wichmann D, Sperhake J-P, Lütgehetmann M, Steurer S, Edler C, Heinemann A, Heinrich F, Mushumba H, Kniep I, Schröder AS, Burdelski C, de Heer G, Nierhaus A, Frings D, Pfefferle S, Becker $\mathrm{H}$, Bredereke-Wiedling $\mathrm{H}$, de Weerth A, Paschen HR, Sheikhzadeh-Eggers S, Stang A, Schmiedel S, Bokemeyer C, Addo MM, Aepfelbacher M, Püschel K, Kluge S (2020) Autopsy findings and venous thromboembolism in patients with COVID-19: a prospective cohort study. Ann Intern Med 173:268-277. https:// doi.org/10.7326/M20-2003

13. Wenzel P, Kopp S, Göbel S, Jansen T, Geyer M, Hahn F, Kreitner KF, Escher F, Schultheiss HP, Münzel T (2020) Evidence of SARS-CoV-2 mRNA in endomyocardial biopsies of patients with clinically suspected myocarditis tested negative for COVID-19 in 
nasopharyngeal swab. Cardiovasc Res 116:1661-1663. https://doi. org $/ 10.1093 /$ cvr/cvaa160

14. Buja LM, Wolf DA, Zhao B, Akkanti B, McDonald M, Lelenwa L, Reilly N, Ottaviani G, Elghetany MT, Trujillo DO, Aisenberg GM, Madjid M, Kar B (2020) The emerging spectrum of cardiopulmonary pathology of the coronavirus disease 2019 (COVID-19): report of 3 autopsies from Houston, Texas, and review of autopsy findings from other United States cities. Cardiovasc Pathol 48: 107233. https://doi.org/10.1016/j.carpath.2020.107233

15. Veronese G, Ammirati E, Chen C, Klingel K, Suzuki M, Okumura T, Maisch B, Zuo H, Ni L, Jiang J, Zhang J, Wang H, Zhou N, Tschope C, Cooper LT, Wang DW (2020) Management perspectives from the 2019 Wuhan international workshop on fulminant myocarditis. Int J Cardiol. https://doi.org/10.1016/j.ijcard.2020.10. 063

16. Tavazzi G, Pellegrini C, Maurelli M, Belliato M, Sciutti F, Bottazzi A, Sepe PA, Resasco T, Camporotondo R, Bruno R, Baldanti F, Paolucci S, Pelenghi S, Iotti GA, Mojoli F, Arbustini E (2020) Myocardial localization of coronavirus in COVID-19 cardiogenic shock. Eur J Heart Fail 22:911-915. https://doi.org/10.1002/ejhf. 1828

17. Bojkova D, Wagner JUG, Shumliakivska M, Aslan GS, Saleem U, Hansen A, Luxán G, Günther S, Pham MD, Krishnan J, Harter PN, Ermel UH, Frangakis AS, Milting H, Zeiher AM, Klingel K, Cinatl J, Dendorfer A, Eschenhagen T, Tschöpe C, Ciesek S, Dimmeler S (2020) SARS-CoV-2 infects and induces cytotoxic effects in human cardiomyocytes. Cardiovasc Res 116:2207-2215. https://doi. org/10.1093/cvr/cvaa267

18. Albert CL, Carmona-Rubio AE, Weiss AJ, Procop GG, Starling RC, Rodriguez ER (2020) The enemy within: sudden-onset reversible cardiogenic shock with biopsy-proven cardiac myocyte infection by severe acute respiratory syndrome coronavirus 2 . Circulation 142:1865-1870.https://doi.org/10.1161/ CIRCULATIONAHA.120.050097

Publisher's note Springer Nature remains neutral with regard to jurisdictional claims in published maps and institutional affiliations. 